\title{
Erratum: An analysis of the effects of equalisation funds on service delivery in selected local authorities in Zambia
}

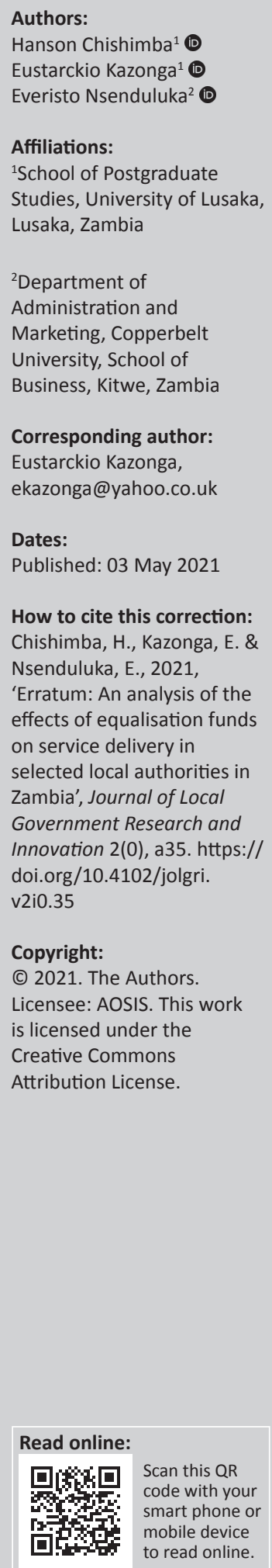

\section{Copyright:}

(C) 2021. The Authors.

Licensee: AOSIS. This work

is licensed under the

Creative Commons

Attribution License.

In the version of this article initially published, Chishimba, H., Kazonga, E. \& Nsenduluka, E., 2020, 'An analysis of the effects of equalisation funds on service delivery in selected local authorities in Zambia', Journal of Local Government Research and Innovation 1(0), a14. https:/ / doi. org/10.4102/jolgri.v1i0.14, the article section was given incorrectly. The correct section should be Original Research instead of Review Article.

This correction does not alter the study's findings of significance or the overall interpretation of the study's results. The publisher apologises for any inconvenience caused. 


\section{An analysis of the effects of equalisation funds on service delivery in selected local authorities in Zambia}

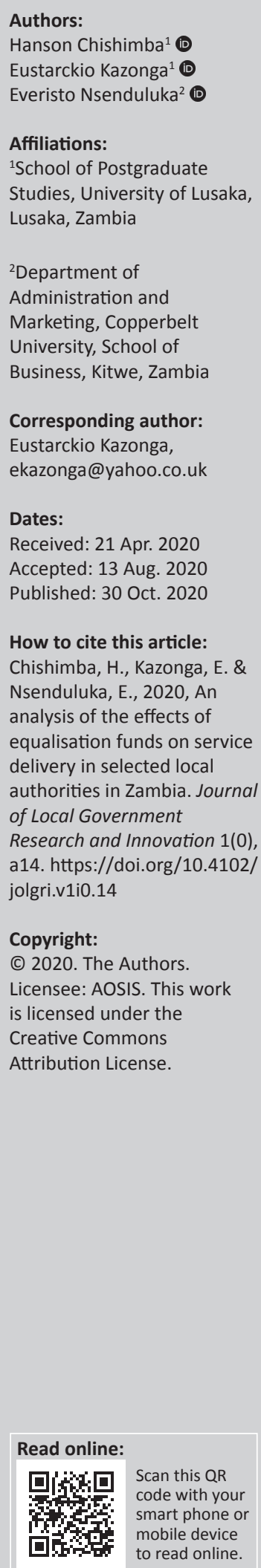

Background: The government of the Republic of Zambia established the Local Government Equalisation Fund, to which each year parliament appropriates not less than $5 \%$ of the total amount of projected income taxes collected for the republic for that financial year. The purpose of the fund is to provide a source of financing for service delivery.

Aim: The goal of this study was to analyse the effects of equalisation funds on service delivery in selected local authorities in Zambia.

Setting: The study focused on Lusaka City Council, Luanshya Municipal Council and Chisamba and Luangwa town councils in Zambia.

Methods: A concurrent mixed-methods approach was used. The population comprised registered property owners and council officials in the selected districts. The sample was drawn using stratified sampling. Data were collected using questionnaires and analysed by using descriptive statistics and regression analysis using the Statistical Package for Social Sciences (SPSS) version 25. Qualitative data were analysed using a narrative approach.

Results: The expenditure composition of the equalisation funds shows that expenditure on personal emoluments accounts for a greater proportion than capital and service expenditure. There were similarities and differences in the methods of service delivery among local authorities: the use of local government enterprise, contracting out, franchises, volunteers, self-help groups and in-house provision.

Conclusion: There is lack of satisfactory adherence to the guidelines on utilisation of equalisation funds for service delivery as espoused by the central government. The local authorities studied do not adhere to the prescribed guidelines on the utilisation of equalisation funds.

Keywords: equalisation funds; financing; local government; local revenue; fiscal capacity; revenue base; service delivery.

\section{Introduction}

The law and mandate relating to local authorities in Zambia is contained in the Republican Constitution (Amendment) Act no. 2 of 2016, with the meticulous law on local government elaborated in the Local Government Act no. 2 of 2019. The Zambian constitution, as amended in 2016, holds that a local authority shall administer the district, oversee programmes and projects, make by-laws and perform other prescribed functions in the district. Assuredly, the amended constitution provides for the establishment of a sound, reliable and predictable financial base. This has been done to enhance capacity of local authorities to initiate, plan, manage and execute policies with respect to matters that affect the people and to promote social, spatial, financial and economic planning at the district level.

In the performance of their functions, local authorities face daunting constraints, which have been compounded by the increase in expenditure responsibilities and the unfortunate free rider problem for most council services. Undoubtedly, the fiscal situation of councils has been worsened by the erratic disbursement of fiscal grants and the erosion of the resource base through the interplay of various actions by the central government. The current macroeconomic situation has undermined the capacity of the Zambian population to pay for services provided by the local authorities. Consequently, there has been a failure by local authorities to provide essential services 
at acceptable standards, in addition to perpetual defaults on payments to workers, suppliers and statutory bodies (Lolojih 2008).

Central to the fulfilment of the local government mandate are financial resources, yet most of the service users do not pay for the services rendered by the local authorities; currently, municipalities are owed billions of kwacha, and the ratio is climbing. To finance their operations and provide public services, local authorities collect revenue in the form of property taxes, personal levies, rent, fees and charges. Regrettably, government has taken away all the lucrative sources of income from councils such as sales tax, income tax, road tax and water and electricity charges. This has resulted in the creation of a vicious circle of horizontal and vertical fiscal imbalances owing to the differences between the local tax base and the assigned expenditure responsibilities (Martinez-Vazquez, McLure \& Vaillancourt 2006).

The financial position of local authorities has been worsened by the central government's issuance of statutory instrument number 55 of 2000 and the enactment of the Water and Sanitation Act no. 28 of 1997, which transferred the water and sewerage functions to utility companies, as well as the 1997 amendment of the Rating Act, which drastically exempted a number of rateable properties (Government of Zambia SI 55 of 2000, Rating Act amendment no. 12 of 1997). Consequently, the fiscal and social effect of these changes is manifested in the poor road and drainage systems, uncollected garbage and unsanitary facilities, which is evident in the recent death of over 100 people from a cholera outbreak that affected most towns in Zambia, especially Lusaka, in the year 2018.

The revenue base of local authorities has been diminishing following the government decision to take away most, if not all, of the lucrative sources of income from councils, such as sales tax, income tax, road tax and water and electricity charges. The financial problems worsened in 1992 when the government decided to discontinue funding to councils and scrap the 35\% sales tax, as well as in 1997 with the amendment of the Rating Act, which drastically exempted a number of rateable properties. This has resulted in the creation of a vicious circle of horizontal and vertical fiscal imbalances owing to the differences between local tax base and assigned expenditure responsibilities. No doubt, these imbalances have affected service provision.

To redress the imbalance and ignite development, the central government established the Local Government Equalisation Fund. The establishment of the Local Government Equalisation Fund, through the Local Government (Amendment) Act no. 12 of 2014, upstretched service expectations of residents within council jurisdictions. It renewed hopes of improved service delivery, improved capital investments and conditions of service within local government spheres. According to the Local Government (Amendment) Act no. 12 of 2014, each year parliament appropriates not less than $5 \%$ of the total amount projected to be collected as income taxes for the republic for that financial year to the Local Government Equalisation Fund. The purpose of the fund is to supplement the financing of councils for the performance of their functions as listed in the first schedule of the Local Government Act no. 2 of 2019. It is disbursed using a formula based on the population residing within the jurisdiction of each council, adjusted by poverty levels to ensure an equitable allocation of the funds across councils. Local authorities are expected to use at least $20 \%$ of the funds received in any financial year to finance capital expenditure, $21 \%$ on service provision and $59 \%$ on personal emoluments ((Local Government [Amendment] Act of 2014). In spite of this financial intervention, residents have seen continued tragedy in inadequacy service delivery. The question arises on the effects of the equalisation fund on service delivery. Therefore, the aim of this research was to analyse the effects of equalisation funds on service delivery in selected local authorities in Zambia.

\section{General objective}

The aim of this research was to analyse the effects of equalisation funds on service delivery in selected local authorities in Zambia.

\section{Specific questions}

- What is the expenditure composition of equalisation funds in local authorities?

- What methods of service delivery are currently in use by local authorities?

- What are the technical, financial and administrative effects of the Local Government Equalisation Fund?

\section{Significance of the study}

By analysing the effects of the Local Government Equalisation Fund on service delivery in selected local authorities in Zambia, the study has contributed to a better understanding of the causes of poor service delivery by local authorities in Zambia. It has helped development stakeholders and government to understand how local authorities utilise the equalisation fund and better appreciate its technical, financial and administrative effects. It has revealed important information on the state of local authorities and their capacities, which are very useful in informing sound policy.

\section{Literature review Functions of local government}

The Zambian Parliamentary Committee on Local Government Accounts of 2019 acknowledges that local authorities are key in socio-economic development as their operations are meant to promote the interests of the local community and ultimately transform the living standards of the people. They are viewed as agents of the government at the grass-root level and are uniquely positioned to enhance and sustain national development. In order to ensure effective service delivery, there is a need for local authorities to have adequate and diversified sources of revenue. This is in addition to 
other sources of revenue for local authorities provided for in the constitution, such as levies and local taxes. However, Pest (2017) warns that equalisation funds cannot lead to egalitarianism across the country.

The assignment of functions to various spheres of government is fundamental to effective and efficient public service delivery. It is the precondition for good local governance. Assignment of functions to local authorities normally focuses on three basic typologies: administrative functions, political functions and fiscal functions. In deciding which functions to relinquish, countries are guided by several principles, such as economies of scale, externalities, equity and heterogeneity of demands (Von Hagen \& Hepp 2000).

Chernick (2000) contends that the assignment of functions across spheres of government has been very difficult to resolve for most countries, including Zambia. However, most countries largely use the principle of subsidiarity. This principle implies assigning functions to the lowest level of government. This is supported by Castells (2001), who argues that local authorities are responsible for the provision of an extensive range of public services in communities, such as transportation, water supply and sanitation, education and health.

\section{Service provision in Zambia}

The continued presence of heaps of uncollected garbage, unkempt burial sites, irregular statutory inspections in market stalls, restaurants and butcheries and poorly maintained local roads manifests the tragedy of inadequacies of local authorities to deliver services. According to Lolojih (2008), the capacity of councils in Zambia to deliver adequate and quality services in an effective, efficient and transparent manner has remained below the expectation of local communities. He argues that councils lack managerial abilities, appropriate technology and financial capacity to deliver services in Zambia. Consequently, local authorities have failed to provide essential services at acceptable standards in addition to perpetual defaults on payments to workers, suppliers and statutory bodies.

\section{Methods of public service provision}

Bell (2011) points out that the provision of public services includes healthcare, education and sanitation, which are key tasks for the central government. He argues that people care about public services and depend on them being delivered well because they underpin human welfare and economic growth. The way local authorities work has an impact on people's confidence or lack of it in the central government.

\section{Revenue and expenditure assignments for local government}

Most local authorities, especially cities in developing countries, face the challenges of availability of financial resources and service provision demands (Borge 2011).
Similarly, Martinez-Vazquez et al. (2006) noted that most cities in developing countries depend on central government transfers, with lesser revenues derived from property taxation and service charges.

Similarly, the Policy Monitoring and Research Centre (2019), in their submission to the Committee on Local Government Accounts, argues that some local authorities have a low resource base as well as a limited capacity to support revenue generation. This has resulted in local authorities being overdependent on government financing through the Local Government Equalisation Fund. This has led to the failure to adhere to the percentage requirements, which state that $80 \%$ of the funds must be utilised by councils for the payment of salaries and provision of services in communities, whilst $20 \%$ must be utilised on capital projects.

\section{Equalisation transfers and service provision}

Stauss (2005) argues that, to solve the problem of inadequate public services, governments make equalisation payments, which are cash payments made by the central government to local authorities, usually with the objective of offsetting differences either in available revenue or in the cost of providing services. Shah (2014, p. 9) identified equalisation objectives and standards in selected countries. For example, Australia uses equalisation to raise the capacity of local authorities to provide services at the same standard with the same revenue effort and same operational efficiency, whilst Canada's objective is to have reasonably comparable levels of public services at reasonably comparable levels of taxation across provinces. In Switzerland, equalisation is used to 'provide minimum acceptable levels of certain public services without much heavier tax burdens in some cantons than others'.

\section{Vertical and horizontal fiscal imbalance}

According to Turley et al. (2018), horizontal fiscal imbalances exist between local authorities in Ireland, and equalisation transfers are used to reduce the disparities in fiscal capacities between bigger councils with more business activity and those with weak economic bases. The authors further state that ' $[i]$ nternational best practice recommends that transfers should be transparent, adequate, stable and predictable'. Turley and McNena (2019) propose that the grants should be 'formula based, using quantifiable and objective indicators that measure either expenditure needs or fiscal capacity, or both'. Herczyński (2018) reports that 'Sweden introduced a very complicated, highly professional and just equalisation system, but over time decided to move towards a much simpler approach'.

In terms of horizontal fiscal imbalances, 'some Local Authorities, because of the nature of their socioeconomic profile and demographic characteristics, have greater expenditure needs or less revenue capacities, or both' (Herczyński 2018). As with other systems of 
intergovernmental fiscal relations, Ireland has an equalisation fund or pool, out of which equalisation transfers are allocated in order to reduce local government fiscal inequalities (OECD 2018; Turkey \& McNena 2018). Turkey and McNena (2018) confirm the existence of horizontal fiscal imbalances in local authorities. They further claim that the use of equalisation transfers is aimed at reducing the 'fiscal disparities between the more urban and bigger councils, where business activity is most prevalent, and the smaller rural councils with weak economic bases'. With this form of horizontal equalisation, funding comes from local authorities with relatively strong revenue bases as opposed to funding coming directly from the central government as a form of vertical equalisation (Boex 2009; Turkey \& McNena 2018).

\section{Gaps}

The literature body on equalisation funds has established that equalisation funds seek to redress inequities that exist along two dimensions of vertical and horizontal fiscal imbalance. The reviewed literature on equalisation transfers and service provision exhibited gaps, which provided rationale for this study; in particular, Martinez-Vazquez et al. (2006), in their analysis, did not factor in the role of differential fiscal capacities and efforts in revenue mobilisation and service delivery.

In spite of the documented significance of local authorities in national development, there has not been adequate empirical investigation on the effect of equalisation funds on service delivery. However, works by Dafflon (2012), Lolojih (2008), Martinez-Vazquez et al. (2006) and Momba (2002) are quite informative and provide useful insights on local government administration and service delivery in general.

\section{Theoretical framework}

The theoretical framework of this study is based on the cost of service theory of taxation, benefit theory and efficiency service theory. The selected theories helped to explain the problem of inadequate service delivery and inherent challenges in the fiscal architecture of local authorities in Zambia.

\section{Cost of service theory of taxation}

This theory implies that the government should tax the citizens according to the cost of service rendered. The government renders certain services to citizens, and the cost of such services should be collectively met by the citizens. The tax an individual should bear must be equal to the cost of benefit they receive (Samuelson 2012). The Local Government Association (2018) asserts that ' $[t]$ he failure to properly fund these services puts the wellbeing of some of the most vulnerable residents at risk'. Under this theory, the central government makes equalisation payments to local authorities to overcome threats of secession and to create a sense of national unity. Furthermore, equalisation fund transfers under this system will inevitably advance social justice and efficiency in market resource allocation because the cost of service will be subsidised and quality guaranteed, ceteris paribus. This theory is relevant in the analysis of the effects of equalisation funds on service delivery as it provides grounds for local government taxation, the amount of taxes and the level of services to be provided by the council using an economically just mechanism.

\section{Efficiency service theory}

This theory postulates that the main purpose of local government is to provide services to the people on the ground, - and it is the most efficient agent for providing those services that are essentially local. Proponents argue that the efficient delivery of some local services is so compelling that, if local government does not exist, something else will have to be created in its place, implying that local government is indispensable (Ebel \&Yilmaz 2002). In light of this, equalisation transfers will supplement local revenue and enhance efficient service delivery by local authorities. Knowledge of local preferences will allow local authorities to design service provision arrangements that embed efficiency considerations in terms of cost and quality.

\section{Methodology}

This research used a concurrent mixed-methods approach to collect, collate, analyse and integrate quantitative and qualitative data. By mixing qualitative and quantitative methods, the research drew interpretations based on the combined strengths of both sets of data in order to understand the research problem under study.

The population comprised registered property owners within the political boundaries of Lusaka, Luanshya, Chisamba and Luangwa local authorities and council officials, as demonstrated in Table 1. The sample was drawn from residential and business property owners, council-appointed officials and councillors using stratified sampling. A total of 636 questionnaires were administered to property owners in Lusaka, Luanshya, Chisamba and Luangwa. Of the total sample, $91 \%$ were responsive whilst $9 \%$ were non-responsive. The registered property owners were partitioned into strata; then, a simple random sample was obtained from each stratum. Thereafter, data were collected from each sampling unit.

The Cochran formula was used to calculate an ideal sample size given a desired level of precision, desired confidence level and an estimated proportion of the attribute present in

TABLE 1: Sample size and strata.

\begin{tabular}{lccccc}
\hline Council & $\begin{array}{c}\text { No. of } \\
\text { registered } \\
\text { property } \\
\text { owners }\end{array}$ & $\begin{array}{c}\text { No. of } \\
\text { residential } \\
\text { property } \\
\text { owners }\end{array}$ & $\begin{array}{c}\text { No. of } \\
\text { business } \\
\text { owners }\end{array}$ & $\begin{array}{c}\text { No. of } \\
\text { council } \\
\text { officials }\end{array}$ & $\begin{array}{c}\text { No. of } \\
\text { councillors }\end{array}$ \\
\hline Lusaka & 63319 & 105 & 79 & 31 & 5 \\
Luanshya & 30150 & 88 & 61 & 9 & 3 \\
Chisamba & 544 & 61 & 41 & 9 & 2 \\
Luangwa & 1250 & 79 & 51 & 10 & 2 \\
\hline
\end{tabular}


the population (Robson 2002). The Cochran formula is as follows:

$n=Z^{2} \frac{p q}{e^{2}}$

where, $e$ is the desired level of precision (i.e. the margin of error), $p$ is the (estimated) proportion of the population that has the attribute in question and $q$ is $1-p$.

The Z-value was obtained from the Z-table.

The research used both primary and secondary sources of data. Primary data were collected from the field through questionnaires. The data were analysed both qualitatively and quantitatively. A narrative approach within qualitative data was used in order to 'tell a story'. Regression analysis was conducted using the Statistical Package for Social Sciences (SPSS) version 25 and Excel package when determining the effects and trends in service provision and the fiscal capacities of local authorities.

\section{Results}

\section{Expenditure composition of equalisation funds}

In determining the expenditure composition of the equalisation funds in local authorities, Table 2 shows that out of the total local government equalisation transfers received, Lusaka City Council, Luanshya Municipal Council and Luangwa and Chisamba town councils spent $5 \%, 16 \%, 0.3 \%$ and 5\%, respectively. These amounts were all below the minimum prescribed $20 \%$ of equalisation grants purposed to finance capital projects. A large proportion of that expenditure (65\%) for Lusaka City was spent on construction and rehabilitation of schools and clinics, whilst $35 \%$ was spent on the purchase of motor vehicles for managers. In 2017, capital expenditure by Lusaka City Council was $18.7 \%$; this was a $0.7 \%$ reduction from the 2016 expenditure. Similarly, the Luangwa and Luanshya councils spent $13 \%$ and $26 \%$ in 2017, showing a reduction of $7.3 \%$ and $10 \%$, respectively, whilst Chisamba spent $25 \%$ in 2017.

Comparatively, expenditure on capital improvements was higher for Lusaka City Council than the other councils. Chisamba and Luangwa councils, however, constructed more schools and clinics and drilled and installed more boreholes and pit latrines than Lusaka and Luanshya councils.

\begin{tabular}{lcccc}
$\begin{array}{l}\text { TABLE 2: Capital expenditure for2016 fiscal year in nominal terms (ZMW/million). } \\
\begin{array}{l}\text { Local } \\
\text { authority }\end{array}\end{array}$ & Total budget & Total LGEF & $\begin{array}{c}\text { Expected 20\% } \\
\text { capital expenditure }\end{array}$ & $\begin{array}{c}\text { Actual expenditure } \\
\text { on capital }\end{array}$ \\
\hline Lusaka & 372311962 & 81445203 & 16289040 & 21096842 \\
Chisamba & 12569478 & 6102321 & 1220464 & 1534200 \\
Luangwa & 12781241 & 8442073 & 1688414 & 1714686 \\
Luanshya & 65987262 & 7340172 & 1464034 & 2645622 \\
\hline
\end{tabular}

Source: Lusaka, Chisamba, Luangwa and Luanshya Councils (2016)

LGEF, Local Government Equalisation Fund.
In terms of service provision, Lusaka City Council, Luanshya Municipal Council and Chisamba Town Council spent $0.2 \%$, $18.4 \%$ and $0.7 \%$ more than the prescribed $21 \%$ on service provision, respectively. On the contrary, Luangwa Town Council spent $2 \%$ below the prescribed minimum of $21 \%$ of the total equalisation fund transfer on service provision in the year 2016. In 2017, Lusaka City Council and Luanshya Municipal Council spent $11 \%$ and $8 \%$ above the prescribed $21 \%$ of equalisation funds on service provision, respectively. However, there was a reduction in real expenditure on service delivery from 2016. Chisamba and Luangwa councils spent $1 \%$ and $2 \%$ below the prescribed threshold of $21 \%$ of the equalisation transfers, respectively. In 2018, Lusaka City Council spent $13 \%$ above the minimum percentage of $21 \%$ on service provision and significantly increased its expenditure in real terms in comparison to 2017. Similarly, Chisamba, Luangwa and Luanshya Municipal Council spent $0.6 \%, 0.2 \%$ and $0.9 \%$ above the minimum threshold, respectively.

To determine the effect of equalisation transfers on service delivery, a regression analysis was conducted. The overall regression model was significant at the $5 \%$ level. An analysis of variance test performed using an alpha level of 0.05 yielded $F(1,391)=89.86, p<0.001, R=0.187$. The analysis revealed that $18.7 \%$ of all variations in service provision is a result of changes in equalisation transfers. This was evident in town councils that had a nearly non-existent revenue base. Without equalisation funds, local authorities can barely provide essential services to its residents.

Regarding methods of service delivery in the provision of council services to the public, Table 3 shows that Lusaka City Council and Luanshya Municipal Council employed various methods: the use of local government enterprise, contracting out, franchise, volunteers, self-help groups and in-house provision. Chisamba and Luangwa town councils used inhouse provision, which was supplemented by local government enterprise and the use of volunteers and selfhelp groups.

\section{Technical, financial and administrative effects of equalisation funds}

In its quest to determine the technical capacity of councils, the study revealed that Lusaka City Council acquired the most service equipment for road maintenance and construction as well as for erection and maintenance of street lights. Furthermore, the council has a maintenance schedule that they do not adhere to. Similarly, as can be seen in Table 3,

TABLE 3: Methods of service delivery used.

\begin{tabular}{lccccccc}
\hline Council & \multicolumn{6}{c}{ Method of service delivery } \\
\cline { 2 - 7 } & In-house & $\begin{array}{c}\text { Local } \\
\text { government } \\
\text { enterprise }\end{array}$ & $\begin{array}{c}\text { Contracting } \\
\text { out }\end{array}$ & Franchise & Volunteers & $\begin{array}{c}\text { Self- } \\
\text { help }\end{array}$ \\
\hline Lusaka & $\checkmark$ & $\checkmark$ & $\checkmark$ & $\checkmark$ & $\checkmark$ & $\checkmark$ \\
Luanshya & $\checkmark$ & $\checkmark$ & $\checkmark$ & $\checkmark$ & $\checkmark$ & $\checkmark$ \\
Chisamba & $\checkmark$ & $\checkmark$ & - & - & $\checkmark$ & $\checkmark$ \\
Luangwa & $\checkmark$ & $\checkmark$ & - & - & $\checkmark$ & $\checkmark$ \\
\hline
\end{tabular}


TABLE 4: Equipment for service provision.

\begin{tabular}{|c|c|c|c|c|c|c|c|c|}
\hline Council & Motor grader & Road roller & Excavator & Front loader & Bulldozer & Dump truck & Motorised scaffold & Trencher \\
\hline Lusaka & $\checkmark$ & $\checkmark$ & $\checkmark$ & $\checkmark$ & $\checkmark$ & $\checkmark$ & $\checkmark$ & \\
\hline Luanshya & $\checkmark$ & - & $\checkmark$ & $\checkmark$ & - & $\checkmark$ & - & - \\
\hline Chisamba & $\checkmark$ & - & - & - & - & $\checkmark$ & - & - \\
\hline Luangwa & $\checkmark$ & - & - & - & - & $\checkmark$ & - & - \\
\hline
\end{tabular}

TABLE 5: Number of technical employees.

\begin{tabular}{|c|c|c|c|c|c|c|}
\hline Council & Civil engineers & Electrical engineers & Water engineers & Health inspectors & Physical planners & Socio-economic planners \\
\hline Lusaka & 11 & 4 & 3 & 14 & 9 & 6 \\
\hline Luanshya & 3 & - & 1 & 4 & 3 & 2 \\
\hline Chisamba & 1 & - & 1 & 2 & 2 & 1 \\
\hline Luangwa & 2 & - & 1 & 2 & 1 & 1 \\
\hline
\end{tabular}

Luanshya Municipal Council has basic equipment for construction and maintenance but no equipment for the erection and maintenance of street lights, and it does not have an existing maintenance schedule. Chisamba and Luangwa town councils only have a motor grader and dump trucks for service provision and do not have any maintenance schedule in place for these machineries. Furthermore, the dump truck for Luangwa Town Council has been not been operational since 2017.

In determining the fiscal effort by councils following the introduction of equalisation transfers, the study revealed that the fiscal effort by Lusaka City Council has been increasing since 2016; out of its total budget, $78 \%$ was internally generated revenue in 2016, whilst in 2017 and 2018, 88\% and $88.3 \%$ were internally generated revenue, respectively. In the case of Chisamba Town Council, the fiscal effort in 2016 was $51 \%$; this decreased to $44 \%$ in 2017 but increased in 2018 to $61 \%$. The internally generated revenue for Luangwa Town Council in 2016 was 33\% of the total revenue but decreased to $30.98 \%$ in 2017. In 2018, the council improved its efforts to reach $51 \%$ of all revenue. Similarly, Luanshya Municipal Council internally generated $88 \%$ of all council revenue. However, the fiscal effort declined in 2017 to $76 \%$ but rose again in 2018 to $80 \%$.

Administratively, Lusaka City Council has 11 civil engineers, 4 electrical engineers, 3 water engineers, 14 health inspectors, 9 physical planners and 6 socio-economic planners. At least one engineer, health inspector and physical planner service a constituency in Lusaka. Luanshya Municipal Council is serviced by three civil engineers, one water engineer, four health inspectors and three physical planners, with two socio-economic planners. Chisamba and Luangwa town councils are serviced by two civil engineers. There is no electrical engineer, one water engineer, one socio-economic planner and two health inspectors in each town. Chisamba has two physical planners, whilst Luangwa has one (Table 5).

\section{Discussion}

\section{Expenditure composition of equalisation funds}

The study showed that most local authorities did not adhere to the prescribed guidelines on the utilisation of equalisation funds. Regarding personal emoluments, the study showed that councils have been increasing their expenditure on personal emoluments since 2016. This rise in expenditure is a result of increased recruitment of personnel by the Local Government Service Commission and an increase in salaries and other conditions of services for council employees that were awarded in 2016 and 2017. This can be seen in the expenditure by Lusaka City Council of $53.8 \%$ of the total equalisation funds in 2016 on emoluments and 49.3\% in 2017. The council increased its expenditure in 2018 to 53.3\%. Luanshya Municipal Council spent 24.6\% in 2016 and increased its expenditure in 2017 and 2018 to $45 \%$ and $65.1 \%$, respectively. Similarly, in 2016, Chisamba and Luangwa town councils spent $53.3 \%$ and 56\%, respectively. In 2017, Chisamba Council increased its expenditure by $1.7 \%$, whilst Luangwa Council increased its expenditure by $12 \%$. Luangwa Council reduced its expenditure to $65.4 \%$ in 2018, whilst Chisamba increased its expenditure to $59.4 \%$ in the same year.

Even though expenditure on personal emoluments increased in all selected local authorities, the study revealed that delayed payment of salaries and statutory pension contribution is so prevalent in these councils that employees do not know their next pay day.

Similarly, the Policy Monitoring and Research Centre (2019), in its submission to the Committee on Local Government Accounts, has argued that some local authorities have a low resource base as well as limited capacity to support revenue generation. This has resulted in them being overdependent on government financing through the Local Government Equalisation Fund. This has led to the failure to adhere to percentage requirements, which state that $80 \%$ of the funds must be utilised by councils for the payment of salaries and provision of services in communities, whilst $20 \%$ must be utilised for implementing capital projects. Most local authorities are utilising the whole amount of the equalisation fund on the payment of salaries and operations, which negatively affects their expenditure on capital projects. Furthermore, delayed disbursement of the equalisation fund by the Treasury to the Ministry of Local Government for subsequent disbursement to local authorities negatively affects their ability to meet their financial obligations as well as the implementation of projects. 
To establish the effect of payment of user fees on service delivery, the study conducted multiple regression analysis. The overall regression model for payment of user fees and garbage collection was statistically significant. The results revealed that $2.7 \%$ of all variability in service provision vis-à-vis garbage collection can be explained by payment of user fees. Implicitly, service provision by local authorities is inversely related to payment of user fees, which are supplemented by the service component of the equalisation funds. Local authorities charge user fees to ensure effective supply and demand of services. Only those who pay for the service will have access to the services. This ensures that the right quantities are produced by the local authorities. User fees should not be beyond the reach of most service users because they may inefficiently crowd out consumption of a service.

Smart (2001) adds that there must be an economic link between the user fee and the cost of the services. Considering user fees with respect to economic and legal concerns is important to ensure their validity and success. Local authorities may be interested in funding a municipally provided good or service through user fees rather than through property taxes in order to shift spending to other goods or services, to meet new financial obligations, to encourage users to modify their use or to evaluate the popularity of a specific good or service.

It should be noted that user fees can only be imposed when the services can be priced, such as with water, sewage and electricity. User fees become poor instruments for pricing as they inefficiently crowd out consumers. Objections to user fees are also sometimes espoused because they are regressive, and low-income households may have little access to the services (Bird \& Vaillancourt 1998).

\section{Methods of service delivery}

In determining the methods of service delivery, the study showed that Lusaka City Council and Luanshya Municipal Council employed various methods of service delivery: the use of local government enterprise, contracting out, franchise, volunteers, self-help groups and in-house provision. On the other hand, Chisamba and Luangwa town councils employed in-house provision, supplemented by local government enterprise and the use of volunteers and self-help groups.

The methods of service delivery employed have proved to be very effective in the case of Chisamba and Luangwa, owing to the small population in these areas. Even though Lusaka and Luanshya have tried to employ a number of alternative methods of service delivery, the effectiveness of these methods is still below residents' service expectations. This is in part due to the growth of Zambia's population, which has outpaced local authorities' capacity for service delivery in terms of management, infrastructure and financing. The problem of inadequate service delivery has been compounded by the growing number of residents living in informal settlements, which are characterised by inadequate basic services such as decent housing, clean water, sanitation, refuse collection and roads.

\section{Technical, financial and administrative effects of equalisation funds}

In terms of the machinery necessary for service provision, Lusaka and Luanshya councils have acquired most of the service equipment needed for road maintenance and construction as well as for street light assembly and maintenance. However, all the selected councils have a maintenance schedule that they do not adhere to.

With the introduction of equalisation funds, estimates of revenue and expenditure for local authorities have been increasing. The study showed that between 2016 and 2017, Lusaka City Council increased its budget by $1 \%$ and by $7 \%$ in 2018 , whilst Chisamba increased its budget by $8 \%$ between 2016 and 2017, with a 46\% increase in 2018. Similarly, Luangwa increased its budget by $8 \%$ between 2016 and 2017 with another $8 \%$ in 2018 . On the contrary, Luanshya reduced its budget by $49 \%$ between 2016 and 2017. The council then increased its budget by $85 \%$ in 2018 .

The study revealed that revenue collection by the councils is too low and still remains a challenge. Most service users do not pay charges or levies for the services they receive from the council or their agent. When respondents were asked who should bear the cost of council services, $62.4 \%$ reported that the local authority should finance its operation and cost of service provision, whilst $37.6 \%$ of the respondents said that the users of council services should bear the cost of service provision. What the residents do not know is that service provision depends on the presence of effective demand and the willingness and patriotism of individuals to pay taxes.

The study results are similar to the findings of the Policy Monitoring and Research Centre (2019) on revenue mobilisation by local authorities. It has been argued that Zambia has an adequate legal framework governing domestic resource mobilisation. However, raising sufficient revenue is one of the most intractable problems facing most local authorities, and the majority of councils are unable to meet their statutory functions and obligations. Although local authorities have vast powers to raise and generate their own revenues, few are able to take advantage of this provision because of the fact that their resource base is too small to sustain their operations. As a result, local authorities have accumulated crushing burdens of debt or arrears and are now faced with financial crises.

Similar results were obtained in a survey in Tanzania and Uganda, which indicated that citizens have a general appreciation of the necessity of taxation to support local service provision, but chose non-compliance because of a lack of confidence in the local government. Based on survey data from 2003 to 2006, Fjeldstad et al. (2010) found that 
people were much more positive towards the tax system in 2006 compared to 3 years earlier. This was partly because of the improvements in service delivery, particularly education, health and law and order, and partly because of the reforms that led to less oppressive revenue collection.

Administratively, the study showed that councils are now managed by qualified manpower. Generally, all directors and heads of departments in all selected councils have acquired degrees, including middle managers.

\section{Conclusion}

The study concludes that the selected local authorities do not adhere to the prescribed guidelines for the utilisation of equalisation funds. Generally, local authorities have been spending a large proportion of the equalisation funds on personal emoluments and councillors' allowances, leaving little or nothing for capital improvements. This is partly because of the recent mass recruitment of council employees by the Local Government Service Commission in the period 2016-2018 and an increase in salaries and other conditions of service for council employees.

In determining the methods of service delivery, this study has shown that Lusaka City Council and Luanshya Municipal Council employed various methods of service delivery: - the use of local government enterprise, contracting out, franchise, volunteers, self-help groups and in-house provision. On the other hand, Chisamba and Luangwa town councils employed in-house provision, supplemented by local government enterprise and the use of volunteers and self-help groups.

The employed methods of service delivery have proved to be very effective in the case of Chisamba and Luangwa owing to the small population in these areas. Even though Lusaka and Luanshya have tried to employ a number of alternative methods of service delivery, the effectiveness of these methods is still below residents' service expectations.

The study has revealed that with the introduction of equalisation funds, estimates of revenue and expenditure for local authorities have been rising steadily; whilst councils have been increasing their expenditure, their fiscal effort has been declining, with the exception of Lusaka. This has been compounded by weak collection efficiency, as most service users do not pay charges to the council.

Through this analysis, the paper has established the underlying causes of inadequate service delivery by local authorities in Zambia. It has provided relevant information on the expenditure composition of local authorities vis-à-vis the utilisation of equalisation transfers. Local authorities have not been adhering to the guidelines on utilisation of equalisation funds as espoused by the central government.

The research has identified inherent inadequacies in service delivery models used by local authorities in Zambia and the functional assignment of expenditure and revenue by the central government. Arising from these inadequacies, the study recommends that the central government and local authorities redesign the current revenue structure and strengthen financial management. In addition, local authorities should increase their reliance on their own revenue with meaningful discretion. This will strengthen the link between benefits and costs of local services, making local officials more accountable to taxpayers and more fiscally responsible.

\section{Recommendations}

Arising from the service inadequacies, the following recommendations are given to make councils functionally and financially vibrant:

- The central government and local authorities should redesign the current revenue structure and strengthen finance management. Local authorities should enhance their collection efficiency and link collected revenue with expenditure.

- Local authorities should increase their reliance on their own revenue with meaningful discretion. This will strengthen the link between benefits and costs of local services, making local officials more accountable to taxpayers and more fiscally responsible.

\section{Acknowledgements Competing interests}

The authors have declared that no competing interests exist.

\section{Authors' contributions}

H.C. conceptualised the research study and contributed to data collection, analysis and drafting of the article. E.K. contributed to the drafting of data collection instruments, analysis of data and structuring of the article. E.N. contributed to the drafting of the data collection instruments and drafting of the article.

\section{Funding information}

This research received no specific grant from any funding agency in the public, commercial or not-for-profit sectors.

\section{Data availability statement}

Data sharing is not applicable to this article as no new data were created or analysed in this study.

\section{Disclaimer}

The views and opinions expressed in this article are those of the authors and do not necessarily reflect the official policy or position of any affiliated agency of the authors.

\section{Ethical consideration}

Informed consent was obtained from respondents in order to ensure that all respondents participated freely and voluntarily. Confidentiality was guaranteed before 
embarking on data collection from respondents. Furthermore, the respondents were free to withdraw from the study if they felt uncomfortable. Ethical concerns were taken into consideration in the study. Ethical approval was sought from the University of Lusaka Research Ethics Clearance Committee (UNILUSREC). The study received UNILUSREC approval number IORG0010092-002.

\section{References}

Bell, G., 2011, 'Local government size and efficiency in capital-intensive services: What evidence is there of economies of scale?', in S. Lago-Peñas \& J. Martinez Vazquez (eds.), The challenge of local government size, pp. 148-170, Edward Elgar, Cheltenham.

Bird, R.M. \& Vaillancourt, F., 1998, Fiscal decentralization in developing countries, Cambridge University Press, Cambridge.

Boex, J., 2009, Fiscal decentralisation and intergovernmental finance reform as an international development strategy, IDG working paper No. 2009-06.

Borge, L.E., 2011, Local equalization grants: Purpose, efficiency effects, and design, IEB's Word Report on Fiscal Federalism.

Castells, A., 2001, 'The role of intergovernmental finance in achieving diversity and cohesion: The case of Spain', Local Government Journal 19(2), 3-10. https://doi. org/10.1068/c0053

Chernick, H., 2000, 'Federal grants and social welfare spending: Do state responses matter', National Tax Journal 53(1), 143-152. https://doi.org/10.17310/ ntj.2000.1.08

Dafflon, B., 2012, Voluntary amalgamation of local government: The Swiss debate in the European context, International Centre for Public Policy Working Paper Series, Andrew Young School of Policy Studies, Georgia State University, Atlanta, Georgia.

Ebel, R. \& Yilmaz, S., 2002, 'On the measurement and impact of fiscal decentralisation', Journal of Public Economics 1(4), 521.

Fjeldstad, O., Katera, L., Msami, J. \& Ngalewa, E., 2010, Local government finance and financial management in Tanzania: Empirical evidence of trends 2000-2007, REPOA Special paper No. 10-2010, Research on Poverty Alleviation, Dar es Salaam.

Government of Zambia, 1997, Rating Act amendment No. 12, Government Printers, Lusaka.

Government of Zambia, 2000, Statutory instrument No. 55, Government Printers, Lusaka.
Herczynski, J., 2018, Five European systems of local government finance. SKL International, Warsaw, Poland. https://doi.org//10.2139/ssrn.3382179

Lolojih, P., 2008, Local government administration and service delivery in the third republic, University of Zambia Press, Lusaka.

Local Government (Amendment) Act No. 2. (2014). Government of the Republic of Zambia. Government Printers, Lusaka.

Local Government Association, 2018, Fiscal architecture of local authorities, LGAZ, Lusaka.

Martinez-Vazquez, J., McLure, C. \& Vaillancourt, F., 2006, 'Revenues and expenditures in an intergovernmental framework', in R.M. Bird \& F. Vaillancourt (eds.), Perspectives on fiscal federalism, pp. 15-34, The World Bank Publication, Washington, DC.

Momba, J.C., 2002, Report on problems of effectiveness in service delivery, accountability and transparency of local authorities in Zambia, TI-Zambia, Lusaka.

OECD, 2018, Subnational Government in OECD cCountries: Key data. 2018 ed.ition, OECD Publishing, Paris.

Pest, P., 2017, Local Revenue mobilization. Lessons for Subnational Government, Wroclaw review of Law, Administration and Economics, Poland, Warsaw.

Policy Monitoring and Research Centre, 2019., Policy Rreview, Lusaka, PMRC.

Robson, C., 2002, Real world research: A resource for social scientists and practitioner researchers, 2nd edn., Blackwell, Oxford.

Shah, A., 2014., 'Principles and the practice of fiscal equalization transfers with special emphasis on solidarity or Robin Hood Programs', The Ministry of Finance, Poland and the World Bank Workshop on "Fiscal Equalization Transfers - International Practices: Lessons for Poland", Warsaw, Poland, December 11-12.

Samuelson, P., 2012, Diagrammatic exposition of a theory of public expenditure, University of California, Santa Barbara, CA.

Smart, M., 2001, 'Redistribution, risk, and incentives in equalization: A comparison of RTS and macro approaches', paper presented to conference on equalization, Institute of Intergovernmental Affairs, School of Policy Studies, Queen's University, Kingston, Canada. 04-07 December.

Stauss, B., 2005, 'Customer frustration in loyalty programs', International Journal of Service Delivery Industry Management 16(3), 229-252. https://doi. org/10.1108/09564230510601387

Turley, G., McNena, S. \& Robins, G., 2018, 'Austerity and Irish local government expenditure since the great recession'. Administration, 66(4):1-24. https://doi. org/10.2478/admin-2018-0030

Turley, G, \& McNena, S., 2019, 'Financing local government in the twenty first century: Local government revenues in European Union Member Saes. 2000-2014, in R. Kerley, J. Liddle \& P.T. Duning (eds), Routledge Hand book of international local government, pp. 496-517, Routledge, London.

Von Hagen, J. \& Hepp, R., 2000, Regional risk sharing and redistribution in the German Federation, Working Paper, ZEI, University of Bonn, North Rhine-Westphalia, Germany. 